\title{
Recent Curriculum Reforms at the Basic Education Level in Nigeria Aimed at Catching Them Young to Create Change
}

\author{
Charity O. Igbokwe* \\ Department of Early Childhood Education, College of Education, Afaha- Nsit, Akwa Ibom State, Nigeria \\ *Corresponding author: igbokweco@yahoo.com
}

Received October 04, 2014; Revised December 22, 2014; Accepted January 07, 2015

\begin{abstract}
The Universal Basic Education (UBE) Programme was introduced in Nigeria in September, 1988. Following this, in 2008 the Federal Government of Nigeria, through the Nigerian Educational Research and Development Council (NERDC) developed and introduced the 9-Year Basic Education Curriculum (BEC) in schools by realigning all extant Primary and Junior Secondary School Curricula to meet the key targets of the UBE programme. In view of some contemporary and national concerns and to make the curriculum more practical, relevant, interest generating to the young learners and in line with global best practices, the 9-year BEC was recently revised in 2012 and its implementation has just commenced in September, 2014. This article is focused on the structure, special features and the implementation strategy of the Revised 9-Year Basic Education Curriculum with some emphasis on the Basic Science and Technology component as one of the key cluster subjects prepared with the aim of catching the young learner to love science, learn science and create change in the learners environment.
\end{abstract}

Keywords: education, curriculum, science, technology and structure

Cite This Article: Charity O. Igbokwe, "Recent Curriculum Reforms at the Basic Education Level in Nigeria Aimed at Catching Them Young to Create Change.” American Journal of Educational Research, vol. 3, no. 1 (2015): 31-37. doi: 10.12691/education-3-1-7.

\section{Introduction}

The world today is undergoing major transformations. The global transformations are multidimensional, affecting the technological, economic, social, cultural and political development of human communities particularly those of developing societies like Nigeria. Education in the generic and global context is a strategic instrument for social and economic transformation. The focus of education system all over the world is the development of the human capital required to meet present and future challenges of globalization and knowledge economy (Dike, 2004). Consequently, the Second International Congress on Technical and Vocational Education held in Seoul, Korea identified challenges that would inform changes in education worldwide as:

- Population growth and rapid urbanization;

- Poverty and lack of skills for income generation; and

- Low participation rate in technical and vocational education (Obioma, 2011).

Hence the National Economic Empowerment and Development Strategy (NEEDS) recognizes that Nigeria's economy could only be transformed and sustained through education that empowers the people and assures the technological development of the country. No wonder education is a foundational component of Nigeria Transformation Agenda and Vision 202020. Hence between 2008 and now, the country has witnessed two major curriculum reform initiatives at the Basic Education level, namely:

1. The 9-Year Basic Education Curriculum (BEC) (September 2008- August 2014); and

2. The Revised 9-Year Basic Education Curriculum (September 2014 -Present).

\section{Aim}

The purpose of this article is to review the philosophy and structure of both the 9-Year Basic Education Curriculum and the revised 9-Year Basic Education Curriculum in Nigeria with particular emphasis on the features of the Basic Science and Technolog yCurriculum intended to make the young learners create change in their learning environment. Based on the review, further recommendations are made.

The 9-Year Basic Education Curriculum (BEC) (September 2008- August 2014)

Following the decision of the Federal Government of Nigeria to introduce the Universal Basic Education (UBE) programme in September 1988, the Nigerian Educational Research and Development Council (NERDC) restructured and re-aligned all extant primary and Junior Secondary School (JSS) curricula into 9-Year Basic Education Curriculum for implementation in Nigerian schools with effect from September, 2008. 
The 9-Year Basic Education Curriculum emphasizes value re-orientation, poverty eradication and employment generation capabilities in learners. In these curriculum reform initiatives, science, technology, mathematics, and vocational education and training are specifically designed to provide the contents, learning experiences and skills for the socio-economic transformation of the Nigerian nation.

\section{Procedure}

Using available sources and literature, this article identified the philosophy and structure of the 9-Year and the Revised 9-Year Basic Education Curricula in Nigeria categorized into Lower Basic (Primaries 1-3), Middle Basic (Primaries 4-6) and Upper Basic (Junior Secondaries 1-3), the basic features of the Revised Basic
Education Curriculum, the structure, objectives and features of the Basic Science and Technology Curriculum and the implementation strategies of the curricula.

\subsection{The Structure of the 9-Year Basic Education Curriculum}

The structure of the 9-Year Basic Education Curriculum was such that subject offerings ranged between ten and sixteen from Primary I to JSS III and almost every subject was a stand- alone subject (see Table 1). For example, Basic Science, Basic Technology, Physical \& Health Education, Computer Studies/ICT, Christian Religious Studies/Islamic Studies, Civic Education, Home Economics, Agricultural Science, and Business Studies were all separate subjects (FME, 2008).

Table 1. The Structure of the 9-Year Basic Education Curriculum

\begin{tabular}{|c|c|c|}
\hline Lower Basic education Curriculum & Middle Basic Education Curriculum & Upper Basic Education Curriculum \\
\hline PRIMARY 1-3 & PRIMARY 4-6 & JSS1-3 \\
\hline $\begin{array}{l}\text { Core Compulsory Subjects } \\
\text { 1. English Studies } \\
\text { 2. One Major Nigeria Language (Hausa, Igbo } \\
\text { or Yoruba) } \\
\text { 3. Mathematics } \\
\text { 4. Basic Science and Technology } \\
\text { 5. Social studies } \\
\text { 6. Civic Education } \\
\text { 7. Cultural and Creative Arts (CCA) } \\
\text { 8. Christian Religious Studies/ Islamic } \\
\text { Studies } \\
\text { 9. Physical and Health Education (PHE) } \\
\text { 10. Computer Studies/ICT }\end{array}$ & $\begin{array}{l}\text { Core Compulsory Subjects } \\
\text { 1. English Language } \\
\text { 2. One Major Nigeria Language (Hausa, Igbo } \\
\text { or Yoruba) } \\
\text { 3. Mathematics } \\
\text { 4. Basic Science } \\
\text { 5. Social Studies } \\
\text { 6. Civic Education } \\
\text { 7. Cultural \& Creative Arts } \\
\text { 8. Christian Religious Studies } \\
\text { 9. Physical and Health Education (PHE) } \\
\text { 10. Computer Studies/ ICT }\end{array}$ & $\begin{array}{l}\text { Core Compulsory Subjects } \\
\text { 1. English Language } \\
\text { 2. One Major Nigeria Language (Hausa, Igbo } \\
\text { or Yoruba) } \\
\text { 3. Mathematics } \\
\text { 4. Basic Science } \\
\text { 5. Social Studies } \\
\text { 6. Civic Education } \\
\text { 7. Cultural \& Creative Arts } \\
\text { 8. Christian Religious Studies } \\
\text { 9. Physical and Health Education (PHE) } \\
\text { 10. Basic Technology } \\
\text { 11. Computer Studies/ ICT }\end{array}$ \\
\hline $\begin{array}{l}\text { Elective Subjects } \\
\text { 1. Agriculture } \\
\text { 2. Home Economics } \\
\text { 3. Arabic Language }\end{array}$ & $\begin{array}{l}\text { Elective Subjects } \\
\text { 1. Agriculture } \\
\text { 2. Home Economics } \\
\text { 3. Arabic Language }\end{array}$ & $\begin{array}{l}\text { Elective Subjects } \\
\text { 1. Agriculture } \\
\text { 2. Home Economics } \\
\text { 3. Arabic Language } \\
\text { 4. Business Studies }\end{array}$ \\
\hline $\begin{array}{l}\text { Note: } \\
\text { Must offer } 1 \text { elective but not more than } 2 .\end{array}$ & $\begin{array}{l}\text { Note: } \\
\text { Must offer } 1 \text { electivebut not more than } 2 .\end{array}$ & $\begin{array}{l}\text { Note: } \\
\text { Must offer1 elective, but not more than } 3 \text {. }\end{array}$ \\
\hline
\end{tabular}

Source: NERDC (2008).

The 9-Year Basic Education Curriculum was particularly developed for the attainment of the Education for All (EFA) goals, the critical targets of the National Economic Empowerment and Development Strategies (NEEDS), and the Millennium Development Goals (MDGs). It was developed in response to Nigeria's need for relevant, dynamic and globally competitive education that would ensure that learners at the Basic Education level are capable to compete favourably anywhere in the world in terms of knowledge, skills, techniques, values and aptitude. Thus the 9-Year BEC addressed among other things, the issue of value re-orientation, poverty eradication, critical thinking, entrepreneurship and life skills. Implementation of the 9-Year BEC commenced nationwide, in Primary 1 and JSS 1 classes in September, 2008, while the old curriculum (the 6-3-3-4 Curriculum) was systematically being phased out. The first batch of JSS students graduated in June, 2011 after writing the Basic Education Certificate Examination(BECE). By September, 2014, the cohort of pupils that benefited from the use of BEC at the primary school level entered class one of the Junior Secondary School.

\subsection{The Revised 9-Year Basic Education Curriculum (September, 2014 -Present)}

Nevertheless, the school curriculum is a dynamic and open document that is constantly changing with the needs, challenges and aspirations of the society. Thus in the light of the feedback on the implementation of the 9-Year BEC received and the contemporary global and national concerns, the Nigerian government revised the 9- Year BEC in 2012 in line with global best practices as in Kenya -7 subject, Tanzania- 8 subject, United States of America 6 subject, Malaysia and Indonesia -9 subject offerings (Obioma, 2012). The curriculum revision process involved identification and grouping of related disciplines such as Christian Religious Studies/ Islamic Studies, Social Studies, Civic Education, and Security Education to create a new composite or cluster of Revised BEC subject called Religion and National Values. Key concepts in the former curricula now form integrating threads for organizing the contents of the new subject into a coherent whole.

\section{Philosophy of the Revised 9-Year Basic Education Curriculum}

Every learner who has gone through the 9 years of basic education should have acquired appropriate levels of literacy, numeracy, manipulative, communicative and life skills; as well as the ethical, moral and civic values needed for laying a solid foundation for a life-long learning; as a basis for scientific and reflective thinking.

The Structure of the Revised 9-Year Basic Education Curriculum

The Revised BEC comprises ten(10) subjects namely: 
1. English Studies, 2. Mathematics, 3. Basic Science and Technology, 4. Religion and National Values,5. Cultural and Creative Arts 6. Business Studies, 7. Nigerian
Languages, 8. Pre-vocational Studies, 9. French, 10. Arabic (FME,2012).

Table 2(a). Lower Basic Education Curriculum (Primaries 1-3)

\begin{tabular}{|c|c|}
\hline Subjects & Explanatory Notes \\
\hline 1. English Studies & $\begin{array}{l}\text { - Official national language } \\
\text { - Medium of instruction in schools } \\
\text { - The subject predisposes itself for the infusion of the following Road Safety Education, Disaster Risk } \\
\text { Reduction Education, Consumer Education. } \\
\text { - Subject includes Literature-in-English }\end{array}$ \\
\hline 2. Mathematics & $\begin{array}{l}\text { - Fundamental discipline for science and technological development } \\
\text { - Important in everyday life }\end{array}$ \\
\hline $\begin{array}{l}\text { 3. Nigerian Languages (One Nigerian } \\
\text { Language) }\end{array}$ & $\begin{array}{l}\text { - National Policy on Education (NPE) stipulates that the medium of instruction should be the language of the } \\
\text { immediate environment of the child. } \\
\text { - Schools are free to select such Nigerian Language to be taught. }\end{array}$ \\
\hline $\begin{array}{l}\text { 4. Basic Science and Technology (BST) } \\
\text { - Basic science } \\
\text { - Basic Technology } \\
\text { - Physical and Health Education } \\
\text { Information Technology (IT) }\end{array}$ & $\begin{array}{l}\text { - Each of the listed components will serve as themes for the Basic Science and Technology Curriculum } \\
\text { - Climate change is part of the Basic Science theme } \\
\text { - Disaster Risk Reduction Education and Consumer Education are infused into Basic Science and Technology } \\
\text { - Curriculum } \\
\text { - Create enabling environment for the subject in all schools by making computer available in schools. }\end{array}$ \\
\hline $\begin{array}{l}\text { 5. Religion and National Values (RNV) } \\
\text { - Christian Religious Studies/Islamic } \\
\text { - Studies } \\
\text { - Cocial Studies } \\
\text { - Security Education }\end{array}$ & $\begin{array}{l}\text { - Listed components will serve as themes in the Religion and National Values Curriculum } \\
\text { - Contents are planned for all children to take Social Studies, Civic education and Security Education themes } \\
\text { - Separate classes should be run for CRS theme and IS theme } \\
\text { - Consumer Education, Disaster Risk Education and Peace and Conflict Resolution curricula are infused into } \\
\text { the Civic Education, Social Studies and Security Education themes } \\
\text { - Create enabling environment for the subject in all schools }\end{array}$ \\
\hline 6. Cultural and Creative Arts (CCA) & - Important for preservation of our cultural heritage and fostering creativity. \\
\hline 7. Arabic Language & - Optional \\
\hline \multicolumn{2}{|c|}{$\begin{array}{l}\text { Note: } \\
\text { - Minimum of } 6 \text { subjects; Maximum of } 7 \text { subjects } \\
\text { - Emphasis should be on basic concepts and their explanations } \\
\text { - Teaching and learning activity must be creative, innovative, and practical. } \\
\text { - Avoid content repetitions across themes and subjects } \\
\text { - Admit only basic contents from old curriculum. }\end{array}$} \\
\hline
\end{tabular}

Source: NERDC, 2013.

\begin{tabular}{|c|c|}
\hline Subjects & Explanatory Notes \\
\hline 1. English Studies & $\begin{array}{l}\text { - Official national language } \\
\text { - Medium of instruction in schools } \\
\text { - The subject predisposes itself for the infusion of the following: Road Safety Education, Disaster Risk } \\
\text { Reduction Education, Consumer Education. } \\
\text { - Subject include Literature-in-English }\end{array}$ \\
\hline 2. Mathematics & $\begin{array}{l}\text { - Fundamental discipline for science and technological development } \\
\text { - Important in everyday life }\end{array}$ \\
\hline $\begin{array}{l}\text { 3. Nigerian Language (One Nigerian } \\
\text { Language) }\end{array}$ & - Schools are free to select such Nigerian language to be taught. \\
\hline $\begin{array}{l}\text { 4. Basic Science and Technology (BST) } \\
\text { - Basic science } \\
\text { - Basic Technology } \\
\text { - } \text { Physical and Health Education } \\
\end{array}$ & $\begin{array}{l}\text { - Each of the listed components will serve as themes for the Basic Science and Technology Curriculum } \\
\text { - Climate change is part of the Basic Science theme } \\
\text { - Disaster Risk Reduction Education and Consumer Education are infused into Basic Science and } \\
\text { Technology Curriculum } \\
\text { - Create enabling environment for the subject in all schools by making computer available in schools. }\end{array}$ \\
\hline $\begin{array}{l}\text { 5. Pre-Vocational Studies } \\
\text { - Home Economics } \\
\text { - Agriculture } \\
\text { - Entrepreneurship }\end{array}$ & $\begin{array}{l}\text { - Each of the listed components will serve as themes for the Pre-Vocational Studies } \\
\text { - Consumer Education is infused into Pre-Vocational Studies } \\
\text { - Create enabling environment for the teaching of pre-vocational studies in schools }\end{array}$ \\
\hline $\begin{array}{l}\text { 6. Religion and National Values (RNV) } \\
\text { - Christian Religious Studies/Islamic } \\
\text { Studies } \\
\text { - Social studies } \\
\text { - Civic Education } \\
\text { - Security Education }\end{array}$ & $\begin{array}{l}\text { - Listed components will serve as themes in the Religion and National Values Curriculum } \\
\text { - Contents are planned for all children to take Social Studies, Civic Education and Security Education } \\
\text { themes } \\
\text { - Separate classes should be run for CRS theme and IS theme } \\
\text { - Consumer Education, Disaster Risk Education and Peace and Conflict Resolution curricula are infused } \\
\text { into the Civic Education, Social Studies and Security Education themes } \\
\text { - Create enabling environment for the subject in all schools }\end{array}$ \\
\hline 7. Cultural \& Creative Arts(CCA) & - Important for preservation of our cultural heritage and fostering creativity \\
\hline 8. French Language & $\begin{array}{l}\text { - Nigeria's second official language } \\
\text { - Nigeria is surrounded by Francophone countries } \\
\text { - The study of French Language will make our children more competitive at the global level. }\end{array}$ \\
\hline 9. Arabic Language & - Optional \\
\hline \multicolumn{2}{|c|}{$\begin{array}{l}\text { - Minimum of } 8 \text { subjects; Maximum of } 9 \text { subjects } \\
\text { - Emphasis should be on basic concepts and their explanations } \\
\text { - Teaching and learning activities must be creative, innovative, and practical. } \\
\text { - Avoid content repetitions across themes and subjects } \\
\text { - Admits only basic contents from old curriculum }\end{array}$} \\
\hline
\end{tabular}


Table 2(c). Upper Basic Education Curriculum (Juniour Secondary 1-3)

\begin{tabular}{|c|c|}
\hline Subjects & Explanatory Notes \\
\hline 1. English Studies & $\begin{array}{l}\text { - Official National Language } \\
\text { - Medium of Instruction in schools } \\
\text { - The subject predisposes itself for the infusion of the following Road Safety Education, Disaster Risk } \\
\text { Reduction Education, Consumer Education. } \\
\text { - Subject include Literature-in-English }\end{array}$ \\
\hline 2. Mathematics & $\begin{array}{l}\text { - Fundamental discipline for science and technology development } \\
\text { - Important of everyday life }\end{array}$ \\
\hline $\begin{array}{l}\text { 3. Nigerian Languages (One Nigerian } \\
\text { Language) }\end{array}$ & - Schools are free to select such Nigerian language to be taught. \\
\hline $\begin{array}{l}\text { 4. Basic Science and Technology (BST) } \\
\text { - Basic science } \\
\text { - Basic Technology } \\
\text { - Physical and Health Education } \\
\text { - Information Technology (IT) }\end{array}$ & $\begin{array}{l}\text { - Each of the listed components will serve as themes for the Basic Science and Technology Curriculum } \\
\text { - Climate change is part of the Basic Science theme } \\
\text { - Disaster Risk Reduction Education and Consumer Education are infused into Basic Science and } \\
\text { Technology Curriculum } \\
\text { - Create enabling environment for the subject in all schools by making computer available in schools. }\end{array}$ \\
\hline $\begin{array}{l}\text { 5. Pre-Vocational Studies } \\
\text { - Home Economics } \\
\text { - Agriculture } \\
\text { - Entrepreneurship }\end{array}$ & $\begin{array}{l}\text { - Each of the listed components will serve as themes for the Pre-Vocational Studies } \\
\text { - Consumer Education is infused into Pre-Vocational Studies } \\
\text { - Create enabling environment for the teaching of pre-vocational studies in schools }\end{array}$ \\
\hline $\begin{array}{l}\text { 6. Religion and National Values (RNV) } \\
\text { - Christian Religious Studies/Islamic } \\
\text { Studies } \\
\text { - Social studies } \\
\text { - Civic Education } \\
\text { - Security Education }\end{array}$ & $\begin{array}{l}\text { - Listed components will serve as themes in the Religion and National Values Curriculum } \\
\text { - Contents are planned for all children to take Social Studies, Civic education and Security Education } \\
\text { themes } \\
\text { - Separate classes should be run for CRS theme and IS theme } \\
\text { - Consumer Education, Disaster Risk Education and Peace and Conflict Resolution curricula are infused } \\
\text { into the Civic Education, Social Studies and Security Education themes } \\
\text { - Create enabling environment for the subject in all schools }\end{array}$ \\
\hline 7. Cultural \& Creative Arts(CCA) & $\begin{array}{l}\text { - Important for preservation of our cultural heritage and fostering creativity } \\
\text { - Tourism is a theme in Cultural and Creative Arts Curriculum }\end{array}$ \\
\hline 8. Business Studies & $\begin{array}{l}\text { - It is desirable for every child to have some idea of business enterprise } \\
\text { - Enterprise is treated in Business Studies } \\
\text { - Consumer Education is infused into Business Studies Curriculum }\end{array}$ \\
\hline 9. French Language & $\begin{array}{l}\text { - Nigeria's second official language } \\
\text { - Nigeria is surrounded by Francophone countries } \\
\text { - The study of French Language will make our children more competitive at the global level }\end{array}$ \\
\hline 10. Arabic Language & Optional \\
\hline \multicolumn{2}{|c|}{$\begin{array}{l}\text { Note: } \\
\text { - Minimum of } 9 \text { subjects; Maximum of } 10 \text { subjects } \\
\text { - Emphasis should be on basic concepts and their explanations } \\
\text { - Teaching and learning activities must be creative, innovative, and practical. } \\
\text { - Avoid content repetitions across themes and subjects } \\
\text { - Admits only basic contents from old curriculum }\end{array}$} \\
\hline $\begin{array}{l}\text { Source: NERDC, } 2013 . \\
\text { Basic Features of the Revised 9- } \\
\text { Curriculum (BEC) } \\
\text { a. Core subjects are English } \\
\text { Language, Mathematics, Basic Sc } \\
\text { Religion and National Values, Cul }\end{array}$ & $\begin{array}{l}\text { Year Basic Education } \\
\text { tudies, one Nigerian } \\
\text { ence and Technology, } \\
\text { ural and Creative Arts, } \\
\text { Businesc Studies }\end{array}$ \\
\hline
\end{tabular}

b. Elective (optional) Subject: Arabic Language

c. French and Pre-Vocational studies are introduced in Primary 4 as core subjects. While Business Studies is introduced as a core subject at the Junior Secondary school level.

d. Basic science and Technology, Religion and National Values and Pre-Vocational Studies are composite subjects

\section{e. Composite Subjects and their Compositions}

i. Basic Science and Technology

Themes:

- Basic science

- Basic Technology

- Physical and Health Education

- Information Technology

ii. Pre-Vocational Studies

Themes:

- Agriculture

- Home economics

iii. Religion and National Values

Themes:

f. The revised curriculum pays particular attention to the teaching of reading. Consequently, the English Studies curriculum for Primaries 1-3 is focused on the teaching of the following reading skills: Concepts of Print, Phonological Awareness, Phonemic Awareness, Phonics, Fluency, Comprehension and Vocabulary Acquisition.

g. The infusion of Drug Abuse Education, Disaster Risk Reduction and Management, Climate Change, Consumer Education and relevant elements of the National Economic Empowerment and Development Strategy (NEEDS) into relevant contents of the curriculum.

h. Teaching and learning emphasis is on skill development: creative thinking skills, entrepreneurial and work skills.

i. The systematic connection between Primary, Junior and Senior Secondary schools curricula contents.

The Revised Basic Education Curriculum Levels

The original structure of the 9-Year BEC is retained.

The Revised 9-Year BEC is presented as:

- Lower Basic Education Curriculum-Primaries 1-3;

- Middle Basic Education Curriculum-Primaries 4-6; 
- UpperBasic Education Curriculum-Junior Secondary, JS 1-3.

The subjects and contents flow systematically and spirally from Primary 1 to JS 3.

In the process of review, particular efforts were made to further reduce content overload, repetition or duplications within and across subjects without compromising depth, appropriateness, and interrelatedness of the curricula content. In addition, the curriculum is organized to ensure continuity and flow of themes, topics and experiences from primary school to junior secondary school levels.

Since the curriculum represents the total experiences to which all learners must be exposed, the contents, performance objectives, activities for both teachers and learners, teaching and learning materials and evaluation guide are provided.

\section{The Basic Science and Technology Curriculum (BSTC)}

Here, it is of interest to examine the rationale, objectives and structure of the Basic Science and Technology Curriculum as a typical case of a composite or cluster subject in the Revised 9-Year BEC. The BSTC (revised, 2012) is a product of the restructuring and integration of four Primary and Junior Secondary School (JSS) BEC, namely: Basic Science, Basic Technology, Physical and Health Education, and Computer Science/Information Technology (IT). The integration of these science curricula became necessary for the following reasons:

1. Recommendations of the Presidential Summit on Education (2010) to reduce the number of subjects offered in Primary and Junior Secondary Schools;

2. Feedback from the implementation of the curricula in schools that identified repetition and duplication of concepts as the major cause of curriculum overload;
3. Need to encourage innovative teaching and learning approaches and techniques that promote creativity and critical thinking in learners;

4. Need to promote the holistic view of science at the Basic Education level for better understanding of contemporary and changing world; and

5. Need to infuse emergent issues that are of national and global concern such as gender sensitivity, globalization, disaster risk reduction, consumer education, climate change and entrepreneurship.

\subsection{The Objectives of Basic Science and Technology Curriculum}

The Basic Science and Technology Curriculum, BSTC (Revised: 2012) is expected to enable the learners:

Develop interest in Science and Technology;

- Acquire basic knowledge and skills in science and technology;

- Apply scientific and technological knowledge and skills to meet contemporary societal needs;

- Take advantage of the numerous career opportunities provided by science and technology;

- Become prepared for further studies in science and technology;

- Avoid drug abuse and related vices;

- Be safety and security conscious.

\subsection{The Structure of the Basic Science and Technology Curriculum}

The thematic approach to content organization was adopted in developing the BSTC in order to achieve a holistic presentation of scientific and technological concepts and skills to learners. The themes and subthemes that formed the integrating threads for the Basic Science and Technology Curriculum are (FME, 2012):

Table 3. The Structure of the Basic Science and Technology Curriculum

\begin{tabular}{|c|c|c|}
\hline \multirow{2}{*}{ Theme } & $\begin{array}{l}\text { Primary } \\
\end{array}$ & 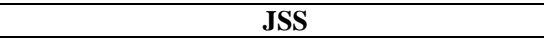 \\
\hline & $\begin{array}{l}\text { Sub-theme } \\
\end{array}$ & $\begin{array}{c}\text { Sub-theme } \\
\end{array}$ \\
\hline Basic Science & $\begin{array}{l}\text { - Exploring our environment } \\
\text { - Living and Non-Living things }\end{array}$ & $\begin{array}{l}\text { - Learning about our Environment } \\
\text { - You and Energy } \\
\text { - Science and Development }\end{array}$ \\
\hline Basic Technology & $\begin{array}{l}\text { - Understanding Basic Technology } \\
\text { - You and Energy }\end{array}$ & $\begin{array}{l}\text { - Understanding Basic Technology } \\
\text { - Materials and Processing } \\
\text { - Drawing Practice } \\
\text { - Tools, Machines and Processes } \\
\text { - Safety }\end{array}$ \\
\hline Physical and Health Education & $\begin{array}{l}\text { - Fundamental Movements } \\
\text { - Basic Movements } \\
\text { - Athletics } \\
\text { - Games and Sports } \\
\text { - Health Education } \\
\text { - Pathogens, Diseases and Prevention } \\
\text { - Drug Eradication } \\
\text { - Responsible Parenthood } \\
\end{array}$ & $\begin{array}{l}\text { - Basic Human Movement } \\
\text { - Sports and Games } \\
\text { - Health Education } \\
\text { - Moving our Body Parts } \\
\text { - Athletics } \\
\text { - Contact and Non-Contact Games }\end{array}$ \\
\hline Information Technology (IT) & $\begin{array}{l}\text { - Basic Computer Operations and Concepts } \\
\text { - Basic Concepts of Information Technology }\end{array}$ & $\begin{array}{l}\text { - Basic Computer Operations and Concepts } \\
\text { - Computer Ethics } \\
\text { - Computer Application Packages } \\
\text { - Basic knowledge of Information Technology }\end{array}$ \\
\hline
\end{tabular}

\subsection{Features of BSTC Intended to Catch Them Young and Create Change}

While selecting the contents, major issues shaping contemporary growth and development of nations, and influencing knowledge driven societies were identified and infused into the curriculum content at every level, from primaries one through to junior secondary classes ; with a progression in infusion of concepts as class advances. These include, but are not limited to: 
a. Environmental Education, b. Climate Change, c. Drug Abuse Education, d. Foods and Drugs Safety Education, e. Disaster Risk Reduction Education, f. Consumer Education, g. Safety and Security, h. Entrepreneurship, i. HIV/AIDS

The topics in each theme are spirally sequenced, from simple to complex across the 9 (nine) years of schooling in order to sustain the interest of learners and promote meaningful learning and skills development. In addition, the curriculum promotes guided inquiry and activity-based teaching and learning using locally sourced materials. Furthermore, the contents of the curriculum are enriched with real-life examples that are not only indigenous and familiar to learners, but also engender the development of relevant attributes and survival strategies for living successfully in contemporary and global world.

BSTC (revised 2012) provides the contents and further learning experiences that will engender the acquisition of functional skills for job creation and wealth generation that will lead to the reduction of poverty within the communities and the nation, at large. The activities are both learner-centered and problem solving -centred, and encourage student-teacher, student-student interaction, working in groups or pairs and student interaction with resource materials.

\section{Implementation Strategy of the Revised 9-Year BEC}

Dike (2014) remarked thatit is not enough to produce curriculum, it is even more important to put in place machinery that will ensure that its ideals are realizable through effective classroom practices. For instance, eventhough the implementation of the Revised 9-Year BEC has just commenced systematically in Primary 1 and JSS 1, it is known (Abakpa, 2013; Akpan, 2012; Okpala, 2011) that the structures and appropriate activities that foster effective implementation of the curriculum are either inadequate or lacking in Nigerian schools. Foremost among the myriad of challenges of Basic Education in Nigeria are the issues of teacher quality and development, lack of enough specialist teachers; dearth of relevant support materials for teachers and inadequate supervision and mentoring of teachers. Thus, to realize the ideals of the 9-Year BEC, relevant support materials that will aid the effective delivery of the curricula content in schools are being provided. Such materials include computers, functional laboratories, learner- centred textual materials prepared by NERDC and some publishers to generate learners' interest and challenge them in innovative and creative thinking. Basic Education teachers are also being trained and retrained in their subject areas on continuous basis, and resources are being provided for the acquisition of consumables and non-consumable items required for teaching and learning of the curriculum contents.

Further to these, the Federal Government of Nigeria through NERDC has produced very detailed teachers guides in each of the ten subjects for effective implementation of the Revised 9-Year BEC. The teachers guide in each subject covers the following seven (7) units on how to:

- Understand the revised curriculum;
- Break the curriculum into syllabus, scheme of work, unit of work and lesson plan;

- Plan lesson using Modern Teaching Approaches;

- Teach topics and concepts that learners find difficult to learn;

- Find, access and develop resources for teaching; and

- Assess learners in each subject area.

Specific innovative classroom practices illustrated in the teachers guides include:

- Purposive learner-learner; teacher-learner and schoolschool collaborations;

- Deployment of ICT and other technologies to support learning;

- Quality interactions (learner-learner, learner- teacher, learner-resource material interactions) taking place in the classroom;

- Issues arising from the learners environment as the focus of teaching and learning activities.

In addition, series of national workshops using interactive and activity -based approaches have been organized to train the teachers in the use of the teachers guides for effective delivery of the contents of the Revised 9-Year Basic Education Curriculum in the ten subject areas. These measures are being taken to ensure effective delivery of the curriculum and hence make the young learners ultimately create change in their environment.

\section{Further Recommendations}

In addition to the implementation strategies discussed above, workshops, in-service training and short courses should be designed to train teachers on how to bring science to the learner as fun, utilizing low- cost materials in the immediate environment of the learner. Such teachers should also be trained on how to integrate information and communication technologies (ICT's) into pedagogy. These measures will help catch the attention of young learners and hence increase their capacity to create change in their environment.

\section{References}

[1] Abakpa, B.O. and Agbo-Egwu, A. O.(2013). Challenges of Attaining MDGs in Nigeria through Mathematics Curriculum Delivery. In: Attaining the MDGs through STEM Education. Okechukwu Abonyi (Ed). Proceedins of $54^{\text {th }}$ Annual Conference of STAN, 3-9.

[2] Akpan B. B.(2011). Science Education in Nigeria: In: Education in Nigeria: From Beginning to the Future. Ivowi U.M.O.(Ed). Lagos: Foremost Educational Services Ltd.

[3] Dike S, (2014). Opening Remarks Presented at the Train-the Trainers Workshop on the Use of the Revised 9-Year Basic Education Curriculum held at Rockview Hotel, Abuja Nigeria, 59th August, 2014.

[4] FME (2008). Teachers Handbook for the 9-Year Basic Education Curriculum: Primary and Junior Secondary School Levels. Lagos: NERDC Press.

[5] FME (2012). The Revised 9-Year Basic Education Curriculum: Basic Science and Technolog. Lagos: NERDC Press.

[6] NERDC(2008). The 9- Year Basic Education Curriculum at a Glance. Lagos: NERDC Press. www.nerdcnigeria.org.

[7] NERDC (2013). The Revised 9-Basic Education Curriculum at a Glance. Lagos: NERDC Press. www.nerdcnigeria.gov.ng.

[8] Obioma G.O(2011). The Project. An address delivered at the Writing Workshop of Teachers Guides for SSS Science Subjects, Dannic Hotels, Enugu, Nigeria, 14-19 $9^{\text {th }}$ Nov., 2011. 
[9] Obioma G.O. (2012). An Address Delivered at the Critique Workshop on Teacher's Guides for the Revised 9-Basic Education curriculum(BEC) Held at NERDC Conference Centre, Lagos Nigeria, 26-28 ${ }^{\text {th }}$ November, 2012.
[10] Okpala P. N. (2011). Reforms in STEM Education. Keynote Address at the $52^{\text {nd }}$ Annual Conference of STAN, held on the $15^{\text {th }}$ $20^{\text {th }}$ August, 2011, Akure, Nigeria. 